\title{
The influence of Perceived Hypermarket Size on Perceived Hypermarket Reputation, Trust and Customer Willingness to Purchase in South Africa
}

\author{
Richard Chinomona*, Osayuwamen Omoruyi \\ School of Economic and Business Sciences, University of the Witwatersrand \\ Vaal University of Technology, South Africa \\ *rchinos@hotmail.com
}

\begin{abstract}
While a remarkable increase in research focusing customer purchase intentions in the retailing industry is noticeable, there is a dearth of studies that have investigated the influence of hypermarket size on customer perceived hypermarket reputation, trust in hypermarket and customer willingness to purchase in the African retailing context. This study used a sample 151 consumers in the Vanderbijlpark town in South Africa to examine these relationships. The results indicate that the proposed five hypotheses are positively supported in a significant way. A discussion of the academic and managerial implications of the results is provided and future research directions are suggested.
\end{abstract}

Keywords: Hypermarket size; Customer trust; Customer perceived hypermarket reputation; Customer willingness to purchase; South Africa

\section{Introduction}

As an emerging economy, South Africa's retailing industry has recently witnessed an increase of hypermarkets. While hypermarkets have been in existence in South Africa for quite a while, the past decade has seen a remarkable shift from convenience stores investment to hypermarkets investment (Neven, Reardon, Chege \& Wang, 2006; Farhangmehr, Marques \& Silva, 2001; Paswan, Pineda \& Ramirez, 2010). This phenomenal shift is beginning to attract the attention of more prospective investors and scholars alike (Barros, 2006). At the centre nerve of the researchers' interest in South Africa are the questions, why hypermarkets? Does store size matter? Is it worth to invest in hypermarkets? An examination of the extant retailing literature seem to indicate that customer satisfaction has been the bedrock of many retailers (Hino, 2010; Farhangmehr et al., 2001; Juhl, Kristensen \& Ostergaard, 2002; Guenzi, Johnson \& Castaldo, 2009). However, what strategy to adopt in order to satisfy these customers appears to be the point of departure separating great achievers from the average performer in the retailing industry. For instance, some retailers believe that hypermarkets provide "one stop store" and therefore attracts more customers (Sand, Oppewal \& Beverland, 2009), while others believe that investing in convenient stores at the proximity of customers is a sure way to satisfy buyers (Woodside \& Trappey, 2001; Alexander \& Silva, 2002). Whatever the argument, nevertheless, there is growing evidence though, indicating that sales growth and profit are associated with store size (Guy, 1995; Daskalopoulou \& Petrou, 2005; Martinez-Ruiz et al., 2010). Unfortunately, instead of focusing more on the influence of store size on customer behavioural outcomes, the bulk of the retailing studies seem to have put more focus on hypermarkets' negative effects on convenient stores market and customer characteristics (e.g. Paswan et al., 2010; Wong \& Dean, 2009:125; Lee, Chang \& Lui, 2010; Hino, 2010:63; Martinez-Ruiz, Jimenez-Zarco \& Izuierdo-Yusta, 2010; Farhangmehr et al., 2001).Besides, most of these studies happen to be from either Europe, the USA or Asia.

Against this backdrop, the purpose of current study therefore, is to fill in this void in two ways. First and foremost, this study seeks to investigate the influence of hypermarket size on customer willingness to purchase in South Africa. Lastly, the study also seeks to examine the mediating role of hypermarket reputation and customer trust in this hypermarket size and customer willingness to purchase relationship. Given that, the current study is one of the few that attempt to investigate the influence of hypermarket size on hypermarket reputation, customer trust and willingness to purchase in the African context - this study is important on two fronts due. First, this study is deemed to contribute new literature to the existing body of retailing literature on hypermarkets from a South African perspective. Second, the current study findings are 
expected to have practical implications to investors and managers in the hypermarket retailing sector. The rest of the paper is arranged as follows: A theoretical review, the conceptual research model and hypotheses development will be presented first. Thereafter the methodology, data analysis and conclusions are discussed. The final section presents the implications of the study, limitations and recommendations for future research.

\section{Literature review}

Hypermarket perceived size: Perceived store size may influence customer trust and willingness to buy (Farhangmehr et al., 2000). Most customer reasons for approaching particular large stores such as supermarkets or hypermarkets are that these large stores provide a variety of design products or service to satisfy the customer needs (Coelho \& Henseler, 2012). By so doing, the customer does not have to go from one small store to the other (Juhl et al., 2002; Noyan \& Simek, 2011; Netemeyer, Heilman \& Maxham, 2012). Thus, the customers are more likely to be willing to buy only if the store can conveniently offer variety of products or services. For example, in South Africa, Pick'n Pay Hypermarket thrives on satisfying diverse individual customer needs, and therefore provides is large in size. In this case the customer may not be motivated to buy in a store that has limited number of goods or service due to its size. According to Bell, Mengüç and Widing (2010), store size is associated with the store management skills training. This therefore may imply that customers are likely to get better in-store shopping experiences and treatment by trained employees in large stores.

Hypermarket perceived reputation: Reputation in this study is defined as "a set of attributes ascribed to a firm, inferred from the firm's past actions" (Yoon, Oh, Song, Kim \& Kim, 2014). How organisations manage their brand reputation determines how customers perceive their product (Beristain \& Zorrilla, 2011). Empirical evidence in the retailing sector, recognise that retailer's reputation is an antecedent to consumer judgments and behaviors (Caruana \& Ewing, 2010). For instance, consumers are likely to attribute high quality of products to the good reputation of the retailer (Suh \& Houston, 2010; Lee \& Shavitt, 2006; Roggeveen, Bharadwaj \& Hoyer, 2007). Drawing from previous studies, reputation is reported to eventually trigger customer willingness to buy (Money, Hillenbrand, Day \& Magnan, 2010). Many retailers today compete to be more reputable in the eyes of the customers through offering competitive value added products and enlarging the retail store's product line in order to satisfy diverse customers' needs (Sweeney \& Soutar, 2001; Caruana \& Ewing, 2010). A consumer's perceived brand reputation is reported in the retailing literature to have an impact on the retailer's performance (Hansen, Samuelsen \& Silseth, 2008; Keh \& Xie, 2009; Veloutsou \& Motinho, 2009). In other words, the more reputable the retailer become in the mind of the customers, the more customers is willing to trust the products sold by the retailer (Jinfeng \& Zhilong, 2009; Magi \& Julander, 1996).

Customer trust and willingness to buy in hypermarket: "Trust is the willingness to rely on an exchange partner in whom one has confidence" (Schoenbachler \& Gordon, 2002). In this study, trust is the expectations held by the customer that the store, its people, and its products are dependable and can be relied on to deliver on their promises. According to Ligas and Chaudhuri (2012), trustworthiness is a factor of risk perception, credibility, past experience, reputation, and perceived dependability. While retailers seek solutions to satisfy customers, the customers are concerned about the risks associated with purchasing form a certain retailer (Guenzi, Johnson \& Castaldo, 2009). When risks are low, the customer is likely to trust the retailer and consequently the willingness to buy from that retailer (Ligas \& Chaudhuri, 2012). Moreover, the empirical literature reports that customers' trust of a retailer's reputation can be a source of sustainable competitive advantage (Li, Li \& Kambele, 2012; Rebollar, Lidon, Serrano, Martin \& Fernandez, 2012). Therefore conversely, the lack of trust in a retailer by customers wills likely results in their unwillingness to buy.

Conceptual model and hypothesis development: A conceptual model is developed in Figure 1, and is drawn from the extant literature on retailing. In this model of four research variables, one variable is a predictor - perceived hypermarket size; two variables are mediators - perceived hypermarket reputation and perceived customer trust; and one outcome variable - customer willingness to purchase. Conceivably, perceived hypermarket size influences customer's perceived hypermarket reputation and trust, and then this 
eventually triggers the customers' willingness to purchase in hypermarkets. Detailed explanations of the associations between these constructs are provided in the hypotheses developed hereafter.

Figure 1: Conceptual Model

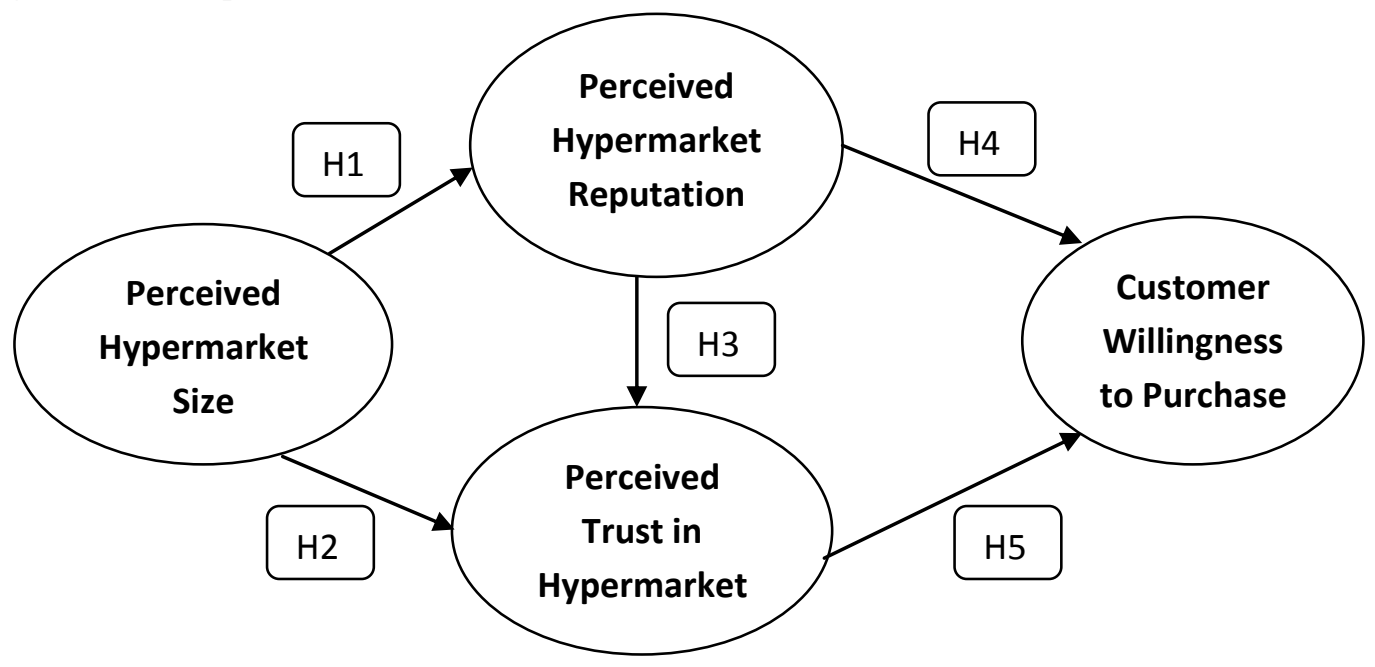

Hypermarket size and perceived reputation: Hypermarket size is the extension/expansion of convenience store, product line and brand name for the purpose of satisfying diverse customers' needs and customer's convenient shopping (Hansen et al., 2008). According to Jinfeng and Zhilong (2009), hypermarket is an emerging market to attract more customers' which may further enhance the way customer perceived the store reputation. Perceive reputation of hypermarket is seen by customers as the ability of the hypermarket to responds to their various needs at the right time and at a given place while cutting cost of going from one connivance store to another (Olavarrieta, Hidalgo, Manzur \& Farias, 2012). Due to the fact that, hypermarket size attract more customers, the perceived reputation may be high due to the fact that hypermarket are able to launch a new product or service and as well able to support a high volume of goods (Stancu, \& Meghisan, 2012). Drawing from this discussion above, this study therefore posits that:

H1: Hypermarket size has a positive influence on hypermarket perceived reputation.

Hypermarket size and perceived customer trust: The size of a hypermarket enables it to conveniently satisfy customer's diverse needs. This is so, because a hypermarket combines a supermarket and a department store but carrying a wide range of products under one roof - including full groceries lines and general merchandise (Schoenbachler \& Gordon, 2002; Corritore, Kracher \& Wiedenbeck, 2003; Beristain \& Zorrila, 2011). According to Liao, Chen, and Wu (2008), the idea behind this may be to build customers' trust by providing consumers with all the goods they require, under one roof and thereby saving time and cost. Hypermarkets therefore provide consumers with comprehensive product options which consequently earn the hypermarkets the customer - even if it does not result in immediate sale (Glen, 2003; Nachiappan \& Anantharaman, 2006; Roberts \& McEvily, 2005). Deducing from the aforementioned arguments, this study postulate that:

H2: Hypermarket size has a positive influence on customer perceived trust in hypermarket

Perceived hypermarket reputation and perceived customer trust: As a collective determinant of dependability (trustworthiness), reputation can be a premise for customers' trust in a hypermarket. The perceived reputation emanates from the customer's overall estimation/believes of the character, quality or standing of a retailer (Suh \& Houston 2010). This overall customer evaluation of the retailer's character is coupled with its ability to continuously meet the customers' needs in a manner that consequently result in their trust (Guenzi et al., 2009; Money et al., 2010). Thus, overtime, a hypermarket's reputation can be expected to lead to customers' trust in that hypermarket (Helm, 2007; Josang, Ismail \& Boyd, 2007). Examples of hypermarkets in South Africa that are generally regarded to have earned the customers' trust are Pick n' pay hyper, Shoprite, Checkers hyper, Macro - among others. Based on the aforementioned discussions, this study therefore, proposes that: 


\section{H3: Hypermarket perceived reputation has a positive influence on perceived customer trust.}

Perceived hypermarket reputation and customer willingness to purchase: Willingness to buy is the readiness, freewill and commitment of a consumer to purchase from a particular retailer. In economics, price triggers the customer willingness to buy, but according to Lee \& Roh (2012), consumers' willingness to purchase can be triggered by the retailer's reputation irrespective of the price of the products. Chen and Li (2009) findings shows that perceived reputation and perceived risk are positively associated with the level of consumers' willingness to buy. They further assert that the question of where to make purchases is not an issue when there is a reputable hypermarket that customers can shop all their needs in a particular place. Thus, the customers' willingness to buy may be driven by how they perceive the hypermarket's reputation. Drawing from the foregoing discussion, this study posits that:

H4: Hypermarket perceived reputation has a positive influence on customer willingness to purchase

Perceived trust in hypermarket and customer willingness to purchase: Hypermarket increase of sales may be as a result of the ability of the hypermarket to continuously build customer trust in the retailer (Chen $\& \mathrm{Li}, 2009$ ). As customers' trust increases, greater lifetime profitability per customer willingness to buy will be achieved (Lee \& Roh, 2012). Urban (2003), argues that "trust-based retailers have higher customer retention and more stable revenue streams". The prediction is that trust-based retailers will, in the end have higher sales volumes and lower marketing costs than competitor because of the customers' willingness to buy based on trust (Helm, 2007). Based on the empirical evidence discussed above, this study therefore, postulates that:

H5: Perceived trust in hypermarket has a positive influence on customer willingness to purchase

\section{Methodology}

Sample and data collection: The target population for the study was South African customers or clients in Gauteng who purchase at hypermarkets such as Checkers, Pick \& Pay, Shop Rite, Spar and Game. Data collection was facilitated by students from the Vaal University of Technology, who were recruited as research assistants to distribute and collect the questionnaire.151 of the distributed questionnaires were usable, out of 170. This, final sample size constitute 89 per cent of the response rate. In order to eliminate differences in response patterns due to different reference points, the respondents were requested to answer the questionnaire with reference to their favourite store brands and their favourite retailer. Where the respondents were not sure, the research assistants guided them as their answered the questionnaire.

Research Measurement Items: Previous research formed the basis upon which the research instruments were formulated and operationalized. However, some modifications were done were necessary in order to suit the research goals. "Customer trust in hypermarket" measure used seven-item scales while "perceived hypermarket size" and "hypermarket reputation" used a three-item scale measure all adapted from Jarvenpaa, Tractinsky and Vitale (2000). Finally, "customer willingness to purchase" used three-item scale measure all adapted from Hellier, Geursen, Carr and Rickard (2003). All the measurement items were measured on a five-point Likert-type scales that was anchored by $1=$ strongly disagree to $5=$ strongly agree to express the degree of agreement.

\section{Results}

Respondent Profile: The respondents were asked to report their demographic information, including gender, age, marital status and education. Out of a sample set of 151, the majority of the respondents females $(59.5 \%)$. The median age group of the respondent was that of less than 30 years $(55.4 \%) .58 \%$ of the respondents were single. About 79.4\% of the respondents had either high school (53\%) or university level of education (26.4\%) and the remainder had primary school (14.9\%) or postgraduate level of education (5.7\%).

Structural Equation Modelling (SEM) Approach: A structural equation modelling approach was used as a data analysis approach. In particular the Smart PL software (Ringle, Wende \& Will, 2005) was used to assess the measurement and structural models. According to Chin \& Newsted (1999) a measurement model is a linkage between the latent variables and their manifest variables while the structural model captures the hypothesized causal relationships among the research constructs. Smart PLS is a component based SEM 
technique that was developed from regression and path analysis. (Chinomona \& Surujal, 2012).Smart PLS has advantages over covariance based SEM techniques such as AMOS in that, it has the ability to model latent constructs that are uncontaminated by measurement error under conditions of non-normality. In addition to that, Smart PLS can handle complex predictive models in small-to-medium sample sizes. As a result of this quality, Smart PLS was found appropriate in case of the current study sample which is relatively small (151). In this respect, In order to check the statistical significance of the relationships, bootstrapping resampling method was used. Table 2 provided below, provides the reliability and validity indicators of the measurement model.

Table 2: Accuracy Analysis Statistics

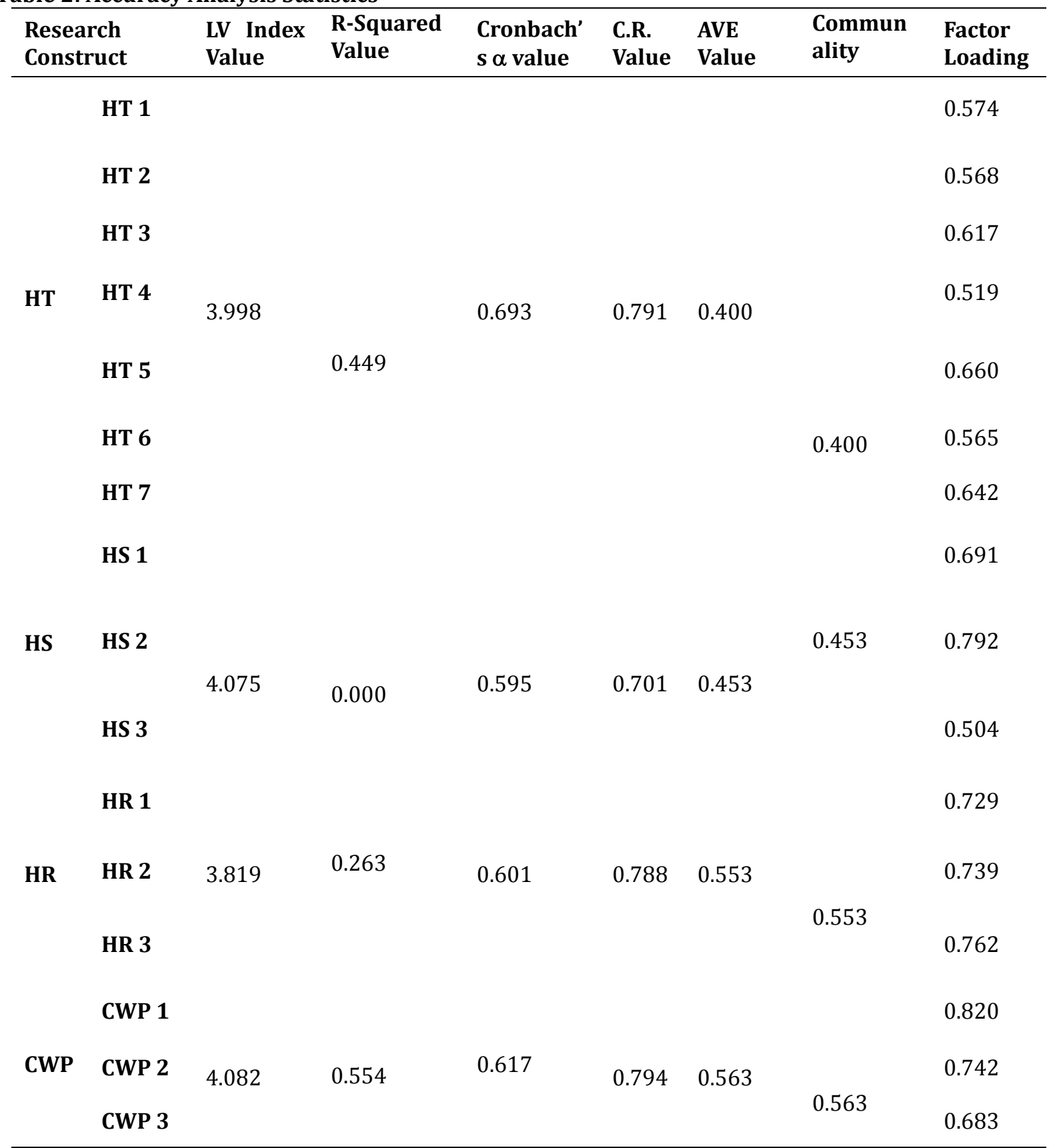

Note: $\mathrm{HT}$ = Hypermarket Trust; HS = Hypermaket Size; HR = Hypermarket Reputation; CWP = Consumer Willingness to Purchase 
Measurement Model: Convergent validity was assessed using the obtained item loadings which were expected to be above 0.5 . Discriminant validity was assessed the inter-construct correlation matrix which was expected to have cross-loading values that are less than 0.85 (Chin, 1998). Drawing from the Table 2 provided below, all item loadings are greater than 0.5 (i.e. ranging from 0.504 to 0.820 ). The cross-loadings of all the constructs are greater than 0.620 , while t-statistics derived from bootstrapping indicate that all the relationships are statistically significant. By and large, the results in Table 2, show that all the measurement items converged well on their respective constructs and that the constructs are distinct from one another hence they are considered acceptable. Chin (1998) suggests that, research variables should have an average variance extracted (AVE) of at least more than 0.4. The composite reliability should be greater than 0.7 (convergent validity), while the inter-construct correlations should be less than the square-root of the AVE (discriminant validity). Drawing from Table 2 provided above, all the research variables exceed these criteria, with CR being 0.7, hence confirming that the research instruments are reliable. In addition to that, the squareroot of the lowest AVE is 0.632 and is greater than the highest inter-construct correlation value (0.621). This confirms too the existence of discriminant validity (See, Table 3).

\section{Table 3: Inter-Constructs Correlations Matrix}

\begin{tabular}{lllll}
\hline Research Variables & HS & HP & HT & CWP \\
\hline Hypermarket Size (HS) & 1.000 & & & \\
Hypermarket Reputation (HP) & 0.621 & 1.000 & & \\
Hypermarket Trustworthiness (HT) & 0.518 & 0.604 & 1.000 & \\
Customer Willingness to Purchase (CWP) & 0.553 & 0.554 & 0.590 & 1.000 \\
\hline
\end{tabular}

Note: HT = Hypermarket Trust; HS = Hypermaket Size; HR = Hypermarket Reputation; CWP = Consumer Willingness to Purchase

Figure 2: Measurement and Structural Model Results

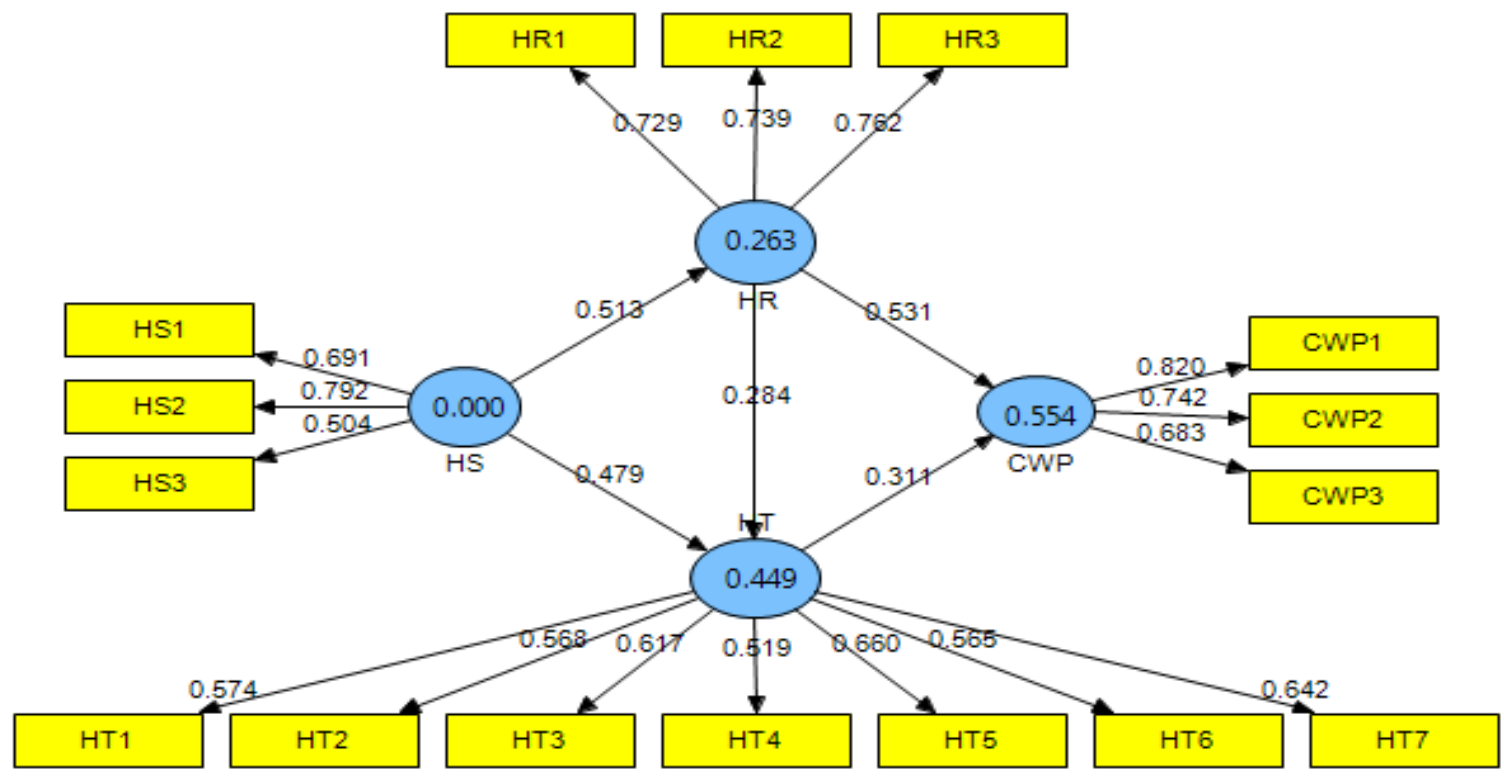

Note: $\mathrm{HT}=$ Hypermarket Trust; HS = Hypermaket Size; HR = Hypermarket Reputation; CWP = Consumer Willingness to Purchase

Path Model: PLS also generates the path coefficients for the relationships modelled among the constructs. The significance of these coefficients was assessed using the bootstrap procedure (with 200 sub-samples) that provided the t-values for each path estimate. Figure 2 and Table 4 presents the results of the PLS analysis on the structural model along with the path estimates and t-values. Support for the study hypotheses, which 
are labelled on their corresponding paths in Figure 2, could be ascertained by examining the directionality (positive or negative) of the path coefficients and the significance of the t-values. The standardized path coefficients are expected to be at least 0.2, and preferably greater than 0.3 (Chin 1998). Figure 2 and Table 4 above provide support for the posited five hypotheses, that is, H1 to H5.The standardised regression weights for $\mathrm{H} 1$ to $\mathrm{H} 5$ are $0.513,0.479,0.284,0.531$ and 0.311 respectively.

Table 4: Path Modelling Results

\begin{tabular}{|c|c|c|c|c|}
\hline Posited Hypothetical Associations & Hypothesis & $\begin{array}{l}\text { Standardised } \\
\text { Regression } \\
\text { Weights }\end{array}$ & $\begin{array}{l}\text { T- } \\
\text { Statistics }\end{array}$ & $\begin{array}{l}\text { Decision } \\
\text { Proposed } \\
\text { Hypothesis }\end{array}$ \\
\hline $\begin{array}{l}\text { Hypermarket Size }(\mathrm{HS}) \quad \rightarrow \text { Hypermarket } \\
\text { Reputation (HR) }\end{array}$ & $\mathrm{H} 1$ & 0.513 & 6.0941 & Supported \\
\hline $\begin{array}{l}\text { Hypermarket Size } \\
\text { Trustworthiness (HT) }\end{array}$ & $\mathrm{H} 2$ & 0.479 & 5.3761 & Supported \\
\hline $\begin{array}{l}\text { Hypermarket Reputation }(\mathrm{HR}) \rightarrow \text { Hypermarket } \\
\text { Trustworthiness (HT) }\end{array}$ & H3 & 0.284 & 2.6324 & Supported \\
\hline $\begin{array}{l}\text { Hypermarket Reputation (HR) } \rightarrow \text { Customer } \\
\text { Willingness to Purchase (CWP) }\end{array}$ & $\mathrm{H} 4$ & 0.531 & 5.3897 & Supported \\
\hline $\begin{array}{l}\text { Hypermarket } \quad \text { Trustworthiness } \\
\text { (HT) } \rightarrow \text { Customer Willingness to Purchase } \\
\text { (CWP) }\end{array}$ & H5 & 0.311 & 3.5521 & Supported \\
\hline
\end{tabular}

Overall, $\mathrm{R}^{2}$ for HR, HT and CWP $(0.263,0.449$ and 0.556 respectively) in Figure 2, indicate that the research model explains at least $26.3 \%$ and at most $55.6 \%$ of the difference in the dependent constructs. Tenenhaus, Vinzi, Chatelin \& Lauro (2005) provides a statistical formula to assess the global goodness-of-fit (GoF) of a research model as provided below:

$\mathrm{GoF}=\sqrt{ } \sqrt{\mathrm{AVE} * \mathrm{R}^{2}}$

The calculated global goodness of fit (GoF) is 0.41. Since this calculate value exceeds the threshold of GoF $>0.36$ suggested by Wetzels, Odekerken-Schröder \& van Oppen (2009), the study confirms the existence of the data's goodness of fit to the research model.

Discussion of Results and Implications of the Study: The results in Table 4 and Figure 2 provide support for five (5) hypotheses (H1, H2, H3, H4, and H5). Hypothesis 1 shows that there is a positive and significant relationship between perceived hypermarket size and perceived hypermarket reputations (0.513). A positive and significant association was postulated between perceived hypermarket size and perceived trust in hypermarket (0.479). Consistent with Hypothesis 2, results indicated that higher levels of perceived hypermarket size will lead to higher levels of perceived hypermarket reputation. Table 4 and figure 2 also indicated that hypothesis 3 has a positive and a significant relationship between perceived hypermarket reputation and perceived trust in hypermarket (0.284). Hypothesis 4 also posits a positive relationship and significant relationship between perceived hypermarket reputation and customer willingness to purchase (0.531). Finally, results in Table 4 and Figure 2, are in line with $\mathrm{H} 5$ and support the reasoning that the higher the level of perceived hypermarket trust the customers have, the higher their willingness to purchase. Therefore there is positive and a significant relationship between customers' perceived trust in hypermarket and customers' willingness to purchase (0.311).

In general, the result of this study is in line with previous research finding as the relationship between the variable as stipulated in figure 2 are found to have positive and significant relationship (Sand et al., 2009; 
Noyan \& Simek, 2011; Netemeyer, Heilman \& Maxham, 2012). As a result of the high competitive rivals between organisations, especially in the retail industries are becoming more proactive in their strategy to gain competitive advantages. Many studies so far have researched about ways the retail industries can attract more customers' willingness to purchase as they are the revenue generator. For example, (Hino, 2010; Farhangmehr et al., 2001; Juhl, Kristensen \& Ostergaard, 2002; Guenzi, Johnson \& Castaldo, 2009). However, there seem to be little evidence of research that focus on the effects of hypermarket size on customer trust, hypermarket reputation and ultimately customer willingness to purchase - particularly in the African hypermarkets retailing sector. Therefore, this study is perhaps long overdue and pertinent to academics and the retailing managers in South Africa.

A significant academic contribution is made to the existing service and retailing literature by exploring the influence of perceived hypermarket size on perceived hypermarket reputation, trust and customer willingness to purchase in South Africa. In particular, the current study findings provide tentative support to the proposition that customers' perceive hypermarket size, perceived hypermarket reputation and customers' trust in hypermarket should be recognized as antecedents and tools that causes customers' willingness to purchase. In addition to that, since this study is one of the few researches that has focused on this matter in the African context, a contribution of new literature to the existing body of retailing literature is made. This generated new literature is expected to be useful to future researchers. On the practitioners' side, customer perceived hypermarket size as well as the perceived hypermarket reputation have a stronger influence on customers' willingness to purchase. Customers' perceived trust in hypermarket according to this study has a lesser influence on customers' willingness to purchase in a hypermarket. Therefore, drawing from this assertion this study suggest that hypermarket retailers or managers who want to identify some ways to attract and retain customers need to consider expanding their business by providing larger shopping space and more varieties of products so as to gain a reputable brand image which eventually precipitate the customers' willingness to buy.

\section{Conclusion}

The purpose of this study was to investigate the influence the influence of perceived hypermarket size on perceived hypermarket reputation, trust and customer willingness to purchase in South Africa. This study proposed five hypotheses and using data collected from Vanderbijlpark town Province in South Africa the posited hypotheses were tested. All the postulated hypotheses were supported in a significant way. Most importantly, the study provide further evidence from an African perspective that perceived hypermarket reputation and customer willingness to purchase are more likely to be influenced by the perceived size of the hypermarket. This therefore, implies that retailers should consider investing in expanding the size of their store size in order to gain a reputation that ultimately triggers customers' willingness to buy.

Limitations and Future Research: Although this study makes significant contributions to both academia and practice, it was limited in some ways, and therefore some future research avenues are suggested. First, the data were gathered from Gauteng Province of South Africa and the sample size of 180 is relatively small. Perhaps, the results would be more informative if the sample size is large and data gathered from the other eight provinces of the country are included. Therefore, future studies may be conducted by using data from other provinces in South Africa. Second, perhaps too, future studies should not be limited to South Africa, but rather consider extending this research to other African countries such as Zimbabwe for results comparison. Future studies can also extend the current research model by include other mediating variables such as customer satisfaction and loyalty to hypermarkets in the hypermarket size - customer willingness to purchase relationship. Above and beyond, this will immensely contribute new knowledge to the existing body of literature on antecedents of customer's willingness to purchase in the hypermarket retailing sector in the African setting - a research context which happens to be neglected in academics.

\section{References}

Alexander, N. \& Silva, M. L. (2002). Emerging markets and the internationalisation of retailing: the Brazilian Experience. International Journal of Retail \& Distribution Management, 30(6), 300-314. 
Barros, C. P. (2006). Efficiency measurement among hypermarkets and supermarkets and the identification of the efficiency drivers. International Journal of Retail \& Distribution Management, 34(2), 135-154.

Bell, S. J., Mengüç, B. \& Widing, R. E. (2010). Salesperson learning, organizational learning, and retail store performance. Journal of the Academy of Marketing Science, 38, 187-201

Berger, M. M. D. (1998). Willingness to pay versus willingness to buy: what define value in healthcare? Value Health, 1(4), 201-203.

Beristain, J. J. \& Zorrilla, P. (2011). The relationship between store image and store brand equity: a conceptual framework and evidence from hypermarkets. Journal of Retailing and Consumer Services, 18, 562574.

Caruana, A. \& Ewing, M. T. (2010). How corporate reputation, quality, and value influence online loyalty. Journal of Business Research, 36, 187-199.

Chen, S. \& Li, J. (2009). Factors influencing the consumers' willingness to buy in e-commerce. E-business \& Information System Security, 9, 1-8.

Chin, W. W. \& Newsted, P. R. (1999). Structural equation modeling analysis with small samples using partial least squares. In Rick Hoyle (Ed). Statistical Strategies for Small Sample Research. Thousand Oaks, CA: Sage. pp. 307-341.

Chin, W. W. (1998). Issues and opinion on structural equation modelling. MIS Quarterly, 22(1), 7-16

Chinomona, R. \& Surujlal, J. (2012). The influence of student internship work experience on their selfimprovement and professionalism in Sport Management. African Journal for Physical, Health Education, Recreation and Dance (AJPHERD), 18, 4(2), 885-899.

Coelho, P. S. \& Henseler, J. (2012). Creating customer loyalty through service customization. European Journal of Marketing, 46(3/4), 331-356.

Corritore, C. L., Kracher, B. \& Wiedenbeck, S. (2003). On-line trust: concepts, evolving themes, a model. International Journal of Human-Computer Studies, 58, 737-758.

Daskalopoulou, I. \& Petrou, A. (2005). Service quality and store performance: some evidence from Greece. Management Service Quality, 15(1), 24-40.

Farhangmehr, M., Marques, S. \& Silva, J. (2000). Consumer and retailer perceptions of hypermarkets and traditional retail stores in Portugal. Journal of Retailing and Consumer services, 7, 197-206.

Farhangmehr, M., Marques, S. \& Silva, J. (2001). Hypermarkets versus traditional retail stores - customers' and retails' perspectives in Braga: a case study. Journal of Retailing and Consumer services, 8, 189198.

Guenzi, P., Johnson, M. D. \& Castaldo, S. (2009). A comprehensive model of customer trust in two retail stores. Journal of Service Management, 20(3), 290-316.

Guy, C. (1995). Retail store development at the margin. Journal of Retailing \& Consumer Services, 2(1), 25-32.

Hansen, H., Samuelsen, B. M. \& Silseth, P. R. (2008). Customer perceived value in B-to-B service relationships investigating the importance of corporate reputation. Industrial Marketing Management, 37, 206-217.

Helm, S. (2007). One reputation or many? Comparing stakeholders' perceptions of corporate reputation. International Journal of Corporate Communications, 12(3), 238-254.

Hino, H. (2010). Antecedents of supermarket formats' adoption and usage: a study in the context of nonwestern customers. Journal of Retailing and Consumer Services, 17, 61-72.

Jarvenpaa, S. L., Tractinsky, N. \& Vitale, M. (2000). Consumer trust in an Internet store. Information Technology and Management, 1, 45-71

Jinfeng, W. \& Zhilong, T. (2009). The impact of selected store image dimensions on retailer equity: evidence from 10 Chinese hypermarkets. Journal of Retailing and Consumer Service, 16, 486-494.

Josang, A., Ismail, R. \& Boyd, C. (2007). A survey of trust and reputation systems for online service provision. Decision Support Systems, 43, 618-644.

Juhl, H. J., Kristensen, K. \& Ostergaard, P. (2002). Customer satisfaction in European food retailing. Journal of Retailing \& Consumer Services, 9, 327-334.

Keh, H. T. \& Xie, Y. (2009). Corporate reputation and customer behavioural intentions: the role of trust, identification and commitment. Industrial Marketing Management, 38, 732-742.

Klemz, B. R. \& Boshoff, C. (2001). Environmental and emotional influences on willingness to buy in small and large retailers. European Journal of Marketing, 35(1/2), 70-91.

Lee, W. I., Chang, C. Y. \& Lui, Y. L. (2010). Exploring customers' store loyalty using the means-end chain approach. Journal of Retailing and Consumer Services, 17, 395-405. 
Lee, J. \& Roh, J. J. (2012). Revisiting corporate reputation and firm performance link. International Journal of Benchmarking, 19(4/5), 649-664.

Lee, K. \& Shavitt, S. (2006). The use of cures depends on goals: Store reputation affects product judgments when social identity goals are salient. Journal of Consumer Psychology, 16(3), 260-271.

Li, G., Li, G. \& Kambele, Z. (2012). Luxury fashion brand consumers in China: perceived value, fashion lifestyle and willingness to pay. Journal of Business Research, 65, 1516-1522.

Liao, S. H., Chen, C. M. \& Wu, C. H. (2008). Mining customer knowledge for product line and brand extension in retailing. Expert System with Applications, 34, 1763-1776.

Ligas, M. \& Chaudhuri, A. (2012). The moderating roles of shopper experience and store type on the relationship between perceived merchandise value and willingness to pay a higher price. Journal of Retailing and Consumer Services, 19, 249-258.

Magi, A. \& Julander, C. R. (1996). Perceived service quality and customer satisfaction in a store performance framework. Journal of Retailing and Consumer Services, 3(1), 33-41.

Martinez-Ruiz, M. P., Jimenez-Zarco, A. I. \& Izuierdo-Yusta, A. (2010). Customer satisfaction's key factors in Spanish grocery stores: evidence from hypermarkets and supermarkets. Journal of Retailing and Consumer Services, 17, 278-285.

Money, K., Hillenbrand, C., Day, M. \& Magnan, G. M. (2010). Exploring reputation of B2B partnerships: extending the study of reputation from the perception of single firms to the perception of inter-firm partnerships. Industrial Marketing Management, 39, 716-768.

Nachiappan, R. M. \& Anantharaman, N. (2006). Evaluation of overall line effectiveness (OLE) in a continuous product line manufacturing system. Journal of Management Technology, 17(7), 987-1008.

Netemeyer, R. G., Heilman, C. M. \& Maxham, J. G. (2012). The impact of a new retail brand in-store boutique and its perceived fit with the parent retail brand on store performance and customer spending. Journal of Retailing, 88(4), 462-475.

Neven, D., Reardon, T., Chege, J. \& Wang, H. (2006). Supermarkets and Consumers in Africa. Journal of International Food \& Agribusiness Marketing, 18(1-2), 103-123

Noyan, F. \& Simek, G. G. (2011). Structural determinants of customer satisfaction in loyalty models: Turkish retail supermarkets. Procedia-Social \& Behavioral Sciences, 30, 2134-2138.

Olavarrieta, S., Hidalgo, P., Manzur, E. \& Farias. (2012). Determinants of in-store price knowledge for packaged products: an empirical study in a Chilean hypermarket. Journal of Business Research, 65, $1759-1766$.

O'Roarty, B., McGreal, S. \& Adair, A. (1998). Clustering retailers by store space requirements: comparable evidence, retail function and rental value. Journal of Property Valuation \& Investment, 16(2), 133-143.

Paswan, A., Pineda, M. D. S. \& Ramirez, F. C. S. (2010). Small versus large retail stores in an emerging market Mexico. Journal of Business Research, 63, 667-672.

Rebollar, R., Lidon, I., Serrano, A., Martin, J. \& Fernandez, M. J. (2012). Influence of chewing gum packaging design on consumer expectation and willingness to buy: an analysis of functional, sensory and experience attributes. Food Quality and Preference, 24, 162-170.

Ringle, C. M., Wende, S. \& Will, A. (2005). Smart PLS 2.0 M3. Available at http://www.smartpls.de. Accessed 23/03/2013

Roberts, P. W. \& McEvily, S. (2005). Product-line expansion and resource cannibalization. Journal of Economic Behaviour \& Organisation, 57, 49-70.

Roggeveen, A., Bharadwaj, N. \& Hoyer, W. (2007). How call centre location impacts expectations of service from reputable versus lesser known firms. Journal of Retailing, 83(4), 403-410.

Sand, S., Oppewal, H. \& Beverland, M. (2009). The effects of in-store themed events on consumer store choice decisions. Journal of Retailing and Consumer Service, 16, 386-395.

Schoenbachler, D. D. \& Gordon, G. L. (2002). Trust and customer wiliness to provide information. Journal of Interactive Marketing, 16(3), 2-16.

Stancu, I. \& Meghisan, G. M. (2012). Marketing study regarding the consumer's behaviour towards the Auchan hypermarkets from Romania. Procedia Economics and Finance, 3, 502-508.

Suh, T. \& Houston, M. B. (2010). Distinguishing supplier reputation from trust in buyer-supplier relationships. Industrial Marketing Management, 39, 744-751.

Sweeney, J. C. \& Soutar, G. N. (2001). Consumer perceived value: the development of a multiple item scale. Journal of Retailing, 77, 203-220. 
Tenenhaus, M., Vinzi, V. E., Chatelin, Y. M. \& Lauro, C. (2005). PLS Path Modeling. Computational Statistics \& Data Analysis, 48(1), 159-205.

Urban, G. L. (2003). The Trust Imperative. MIT Sloan Working Paper No. 4302-03. Available at <SSRN: http://ssrn.com/abstract=400421> or http://dx.doi.org/10.2139/ssrn.400421> accessed: $05 / 13 / 2013$.

Veloutsou, C. \& Motinho, L. (2009). Brand relationships through bran reputation and brand tribalism. Journal of Business Research, 62, 314-322.

Woodside, A. G. \& Trappey, R. J. (2001). Learning why some customers shop at less convenient stores. Journal of Business Research, 54, 151-159.

Wetzels, M., Odekerken-Schröder, G. \& Van Oppen, C. (2009). Using PLS path modelling for assessing hierarchical construct models: guidelines and empirical illustration. Management Information Systems Quarterly, 33(1), 177-195.

Wong, A. \& Dean, A. (2009). Enhancing value for Chinese shoppers: the contribution of store and customer characteristics. Journal of Retailing and Consumer Service, 16, 123-134.

Yoon, S., Oh, S., Song, S., Kim, K. K. \& Kim, Y. (2014). Higher quality or lower price? How value-increasing promotions affect retailer reputation via perceived value. Journal of Business Research, 67, 20882096.

\section{Appendix 1: Measurement Instruments}

\section{Hypermarket Reputation}

This hypermarket is well known.

This hypermarket has a respectable reputation in the market.

Generally, this hypermarket has a good reputation.

\section{Perceived Hypermarket Size}

This hypermarket is a very large company.

This hypermarket is the industry's biggest suppliers on the web.

This hypermarket is a big player in the market.

\section{Hypermarket Trustworthiness}

This hypermarket is trustworthy.

This hypermarket wants to be known as one who keeps promises and commitments.

I trust this hypermarket keeps my best interests in mind.

I find it necessary to be cautious with this hypermarket.

This hypermarket has more to lose than to gain by not delivering on their promises.

This hypermarket's behavior meets my expectations.

This hypermarket could not care more about servicing a person from Vanderbijlpark.

\section{Customer Willingness to Buy}

I am likely that I would return to this hypermarket

It is likely that I would consider purchasing from this hypermarket in the next 3months

It is likely that I would consider purchasing from this hypermarket in the next year

For any purchase, I am likely to buy from this hypermarket 